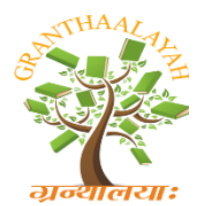

INTERNATIONAL JOURNAL OF RESEARCH GRANTHAALAYAH A knowledge Repository

Science

\title{
EXPERIMENTAL STUDY ON REPLACEMENT OF CEMENT USING SILICA FUME AND FINE AGGREGATE USING GLASS POWDER
}

\author{
A. Rajesh ${ }^{* 1}$, Kai. Kannan ${ }^{2}$, R. Jeevanesan ${ }^{3}$ \\ ${ }^{* 1}$ Assistant Professor, Department of Civil Engineering, St. Joseph's College of Engineering \& \\ Technology, India
}

\begin{abstract}
Increase in population results in increase in usage of materials which cause much pollution to environmental surroundings if not disposed properly. Replacement of costlier building material by disposable waste material is one of best engineering practice in construction. In this paper replacement of cement using silica fume is done up to $20 \%$ and replacement of fine aggregate using glass powder is done up to $40 \%$ also silica fume and glass powder are replaced by $15 \%$ and $20 \%$.compressive strength for replaced materials and conventional concrete is studied for 7 thday and 28th day. From test result it is concluded that glass powder and silica fume is better effective replaceable materials which is cost effective and eco-friendly.
\end{abstract}

Keywords: Silica Fume; Glass Powder; Compressive Strength; Workability and Eco Friendly.

Cite This Article: A. Rajesh, Kai. Kannan, and R. Jeevanesan. (2019). "EXPERIMENTAL STUDY ON REPLACEMENT OF CEMENT USING SILICA FUME AND FINE AGGREGATE USING GLASS POWDER.” International Journal of Research - Granthaalayah, 7(11), 285-293. https://doi.org/10.29121/granthaalayah.v7.i11.2020.368.

\section{Introduction}

Concrete is a combined mixture of cement, fine aggregate, coarse aggregate and water. Its success rates resides durability design, which is done to withstand toughest environments in its life span. Further research is undergoing with addition of various chemical admixtures and supplementary materials for cement. Naturally available supplementary cementitious materials are added those days but due to exhausted condition industrial waste materials are added now days. These additions not only give better result but also save disposal in construction materials industry.

\subsection{Silica Fume}

Silica fume also called as micro silica is an industrial byproduct. While manufacturing ferrosilicon alloy or silicon in electric arc furnace this silica fume is produced. 
Silica fume addition in concrete improves its bond strength, durability and compression strength. Silica fume addition prevents the chloride ion penetration into the reinforcement bars which usually occurs in seashore areas. Addition of silica fume also reduces the permeability of concrete to chloride ions, which protects the reinforcing steel of concrete from corrosion, especially in chloride-rich environments such as coastal regions. Being smaller particle its addition decreases the workability but replacement can be done to specific certain limit.

\subsection{Glass Powder}

Waste glass generation is day by day due to increase in production of glass products. These waste glass products which cannot be recycled are mostly dumped into agriculture land which causes great nuisance to environment. Being non-biodegradable it is a challenging task for everyone in disposing it.

Recent days proper usage of waste materials are appreciated in construction industry. Silica fume and glass powder are cheap waste materials which can be replaced to limited percentages in concrete. In this study, it is also planned to partially replace $(0 \%, 15 \%, 20 \%, 30 \%$ and $40 \%)$ cement and fine aggregate with SF and Glass Powder in concrete.

\subsection{Literature Review}

Dilip Kumar Singha Roy et.al (2012), in their journal, "Effect of Partial Replacement of Cement by Silica Fume on Hardened Concrete" describes an experimental work in silica fume addition and its effect hardened and fresh concrete. From the experimental work it has been observed that on $10 \%$ addition of silica higher compressive strength is achieved, which is higher than $19.6 \%$ of normal concrete.

Vikas Srivastava et.al (2012), in their journal, "Effect of Silica fume on mechanical properties of Concrete" describes the replacement of supplementary cementitious materials (SCMs) is encouraged now a days in construction industry. From the results it is conclude that when silica fume is used as $10 \%$ replacement material for cement it gives high compressive strength. Maximum compressive strength can be achieved in replacing by $10 \%$.

Debabrata Pradhan and Dutta (2013), in their article, "Influence of Silica Fume on Normal Concrete", give detailed information about production of high performance and high strength concrete using silica fume. The replacement is carried at $0 \%, 5 \%, 10 \%, 15 \%$ and $20 \%$ and water cement ratio for 0.40 . For $150 \mathrm{~mm}$ and $100 \mathrm{~mm}$ cube compressive strength is determined for 7 days and 28 days.

Faseyemi Victor Ajileye (2013), in his article, "Investigations on Microsilica (Silica Fume) As Partial Cement Replacement in Concrete". This paper gives detailed report on properties of concrete strength in adding silica fume. This study reveals that at 5 to $10 \%$ silica fume replacement higher compressive strength was developed. This replacement will reduce usage of cement in construction industry at higher levels. 
Iqbal Malik et.al (2013), in their journal, "Study of Concrete Involving Use of Waste Glass as Partial Replacement of Fine Aggregates", describes Fine Aggregate replacement using waste glass powder. The 28 days strength of compressive strength of waste glass powder replaced up to $30 \%$ shows $9.8 \%$ increment. To maintain sustainable construction environment by reducing usage of river sand glass powder plays important role.

Jostin Jose et.al (2014), in their journal, "Use of Glass Powder as Fine Aggregate in High Strength Concrete", describes environmental conservation about usage of glass powder as an alternate material for fine aggregate. This experimental study examines all possible ways of using glass powder in concrete. Fine aggregate was replaced up to $30 \%$ by glass powder.

Haider Ammash et.al (2009), in their journal, "Using of Waste Glass as Fine Aggregate in Concrete", gives the detailed report on the possible usage of waste glass which sizes up to $5 \mathrm{~mm}$ in concrete as well as mortar. The fine aggregate was replaced by waste glass powder with $10 \%$, $20 \%, 30 \%$ and $40 \%$. The result indicates tensile strength and compressive strength of concrete and mortar are decreased on higher replacement. Compressive strength of concrete and mortar was $92 \%$ and $95 \%$ from reference strength for $20 \%$ replacement.

\section{Materials and Methods}

\subsection{Cement}

In general, cement is a binding material, a substance that sets and hardens, and can bind other materials together. Ordinary Portland cement from Zuari Cement Company was used for casting concrete. 53 grade cement confirming to IS: 12269-1987 was used in this study.

\subsection{Water}

By the process called hydration, water causes hardening in concrete. It is a chemical reaction in which the major compounds in cement form chemical bonds with water molecules and become hydrates or hydration products. Addition of more water results is more workability but less strength. Normal potable water can be used for casing and curing of concrete but it have to confirm IS: 456-2000

\subsection{Aggregates}

Aggregates are available in various shapes and sizes depending on type of usage it is selected accordingly. To keep the concrete better economical one 70 to $80 \%$ of volume of aggregates are used in concrete.

In general flat and elongated aggregate particles are neglected and it is limited to $15 \%$ of total volume of aggregate used in casting. If void content in aggregate is more then volume of cement passed required will also be more. To reduce the void content equal size of aggregate selection is best way. 


\subsection{Fine Aggregate}

An aggregate which passes through $4.75 \mathrm{~mm}$ and is retaining on 75 micron sieve is called as fine aggregate. Naturally available river sand confirming to IS2386 (part 1) - 1963 passing through $2.36 \mathrm{~mm}$ sieve was used. The properties of fine aggregate investigated.

\subsection{Coarse Aggregate}

Aggregate that are retained on $4.75 \mathrm{~mm}$ sieve passing through $80 \mathrm{~mm}$ sieve are known as coarse aggregate. Cube specimens casted for M25 mix using coarse aggregates of maximum sizes $20 \mathrm{~mm}$. The physical properties were tested as per IS2386 (part 1) - 1963. Aggregate which confirms IS: 383-1987 was used in this study.

\subsection{Silica Fume (Micro silica)}

Silica fume was collected from industry named Rock fit in tamilnadu. The Silica fume is used as a replacement of cement as specified with IS 15388:2003 specification. During silicon metal production, emitted dust which contains silicon oxide powder is filtered which is finally called as silica fume. It can be utilized as additive material in concrete and cement production industries. Apart from pozzolanic properties, Rock fit Silica fume is good filler because of its particle size distribution. In this study Silica Fume is taken in, 5\%, 10\%, 15\%, 20\% by weight of cement.

\subsection{Glass Powder}

Waste glass is procured from Glass industry, Chennai, India, consists of Waste glass obtained from broken bus glass is used for this project. Using crusher large glass pieces are crushed. To get exact size of fine aggregate it is sieved in $2.36 \mathrm{~mm}$ sieve. Glass powder is replaced by, $5 \%, 10 \%, 15 \%$, $20 \%, 30 \%$ and $40 \%$ by weight of fine aggregate.

\subsection{Mix Proportioning}

For this study, water cement ratio chosen is 0.45 and of concrete of M 25 grade.

\subsection{Preliminary Test on Materials}

\subsubsection{Specific Gravity Test}

Specific gravity was conducted as per IS for fine aggregate, coarse aggregate, glass powder and silica fume.

Specific gravity of fine aggregate $=2.62$

Specific gravity of coarse aggregate $=2.70$

Specific gravity of glass powder $=2.5$

Specific gravity of silica fume $=2.2$ 


\subsubsection{Fine Aggregate Sieve Analysis}

Carried out on IS limits specified in IS: $383-970$

\subsubsection{Concrete Mix Proportion}

Concrete mix proportion is carried as specified in IS: 10262-2009 and cube caste details are tabulated in table 1.1

Table 1.1: Cube cast details

\begin{tabular}{|c|c|c|c|c|c|c|c|c|}
\hline \multirow[t]{2}{*}{ S.no } & \multirow[t]{2}{*}{ Description } & Cement & $\begin{array}{l}\text { Fine } \\
\text { agg. }\end{array}$ & $\begin{array}{c}\text { Coarse } \\
\text { agg. }\end{array}$ & Water & SF & GP & \multirow[t]{2}{*}{$\begin{array}{l}\text { Type Of } \\
\text { Specimen }\end{array}$} \\
\hline & & $(\mathbf{K G})$ & $(\mathbf{K G})$ & (KG) & (KG) & $(\mathbf{K G})$ & $(\mathbf{K G})$ & \\
\hline 1 & Conventional & 11.286 & 16.19 & 30.619 & 5.084 & 0 & 0 & 9 cubes \\
\hline \multicolumn{9}{|c|}{ REPLACEMENT OF CEMENT BY SILICA FUME (SF) } \\
\hline 2 & Silica Fume - 5\% & 6.004 & 9.069 & 17.264 & 2.848 & 0.316 & 0 & 9 cubes \\
\hline 3 & Silica Fume - $10 \%$ & 5.688 & 9.069 & 17.264 & 2.848 & 0.632 & 0 & abes \\
\hline 4 & Silica Fume - $15 \%$ & 2 & 9.069 & 17.264 & 2.848 & 0.948 & 0 & es \\
\hline 5 & Silica Fume - $20 \%$ & 5.056 & 9.069 & 17.264 & 2.848 & 1.264 & 0 & 9 cubes \\
\hline \multicolumn{9}{|c|}{ FINE AGGREGATE REPLACING GLASS POWDER } \\
\hline 6 & Glass Powder $-5 \%$ & 6.32 & 8.616 & 17.264 & 2.848 & 0 & 0.454 & 9 cubes \\
\hline 7 & Glass Powder - $10 \%$ & 6.32 & 8.162 & 17.264 & 2.848 & 0 & 0.907 & 9 cubes \\
\hline 8 & Glass Powder - $15 \%$ & 6.32 & 7.709 & 17.264 & 2.848 & 0 & 1.360 & ubes \\
\hline 9 & Glass Powder - $20 \%$ & 6.32 & 7.255 & 17.264 & 2.848 & 0 & 1.814 & 9 cubes \\
\hline 10 & Glass Powder - 30\% & 6.32 & 6.349 & 17.264 & 2.848 & 0 & 2.721 & 9 cubes \\
\hline 11 & Glass Powder - $40 \%$ & 6.32 & 5.442 & 17.264 & 2.848 & 0 & 3.63 & 9 cubes \\
\hline 12 & Silica Fume - 15\% & 4.221 & 7.123 & 13.356 & 2.236 & 0.745 & 0 & 9 cubes \\
\hline 13 & Glass Powder - $20 \%$ & 4.966 & 5.698 & 13.356 & 2.236 & 0 & 1.424 & 9 cubes \\
\hline \multicolumn{9}{|c|}{ REPLACEMENT OF GLASS POWDER AND SILICA FUME TOGETHER } \\
\hline \multirow[t]{3}{*}{14} & Silica Fume - $15 \%$ & \multirow[t]{2}{*}{9.593} & \multirow[t]{2}{*}{12.95} & \multirow[t]{2}{*}{30.619} & \multirow[t]{2}{*}{5.084} & \multirow[t]{2}{*}{1.692} & \multirow[t]{2}{*}{3.238} & \multirow[t]{2}{*}{9 cubes } \\
\hline & Glass Powder - $20 \%$ & & & & & & & \\
\hline & Total & 062 & 121.8 & 260.59 & 43.12 & 5.598 & 15.55 & 108 cubes \\
\hline
\end{tabular}
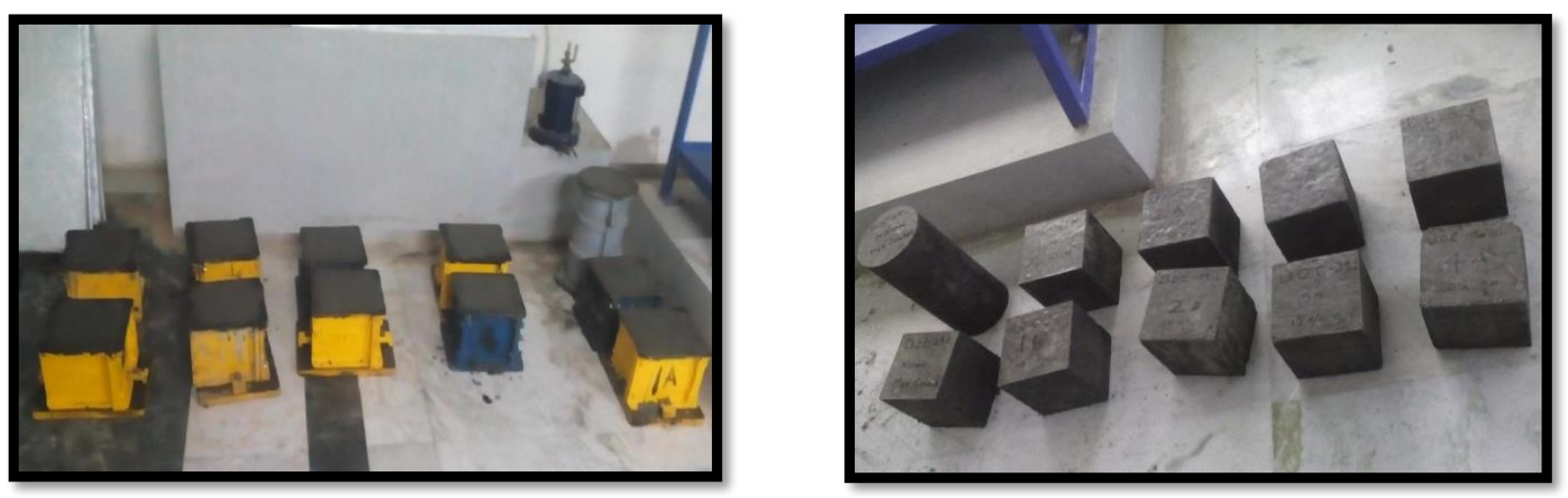

Concrete Casting 


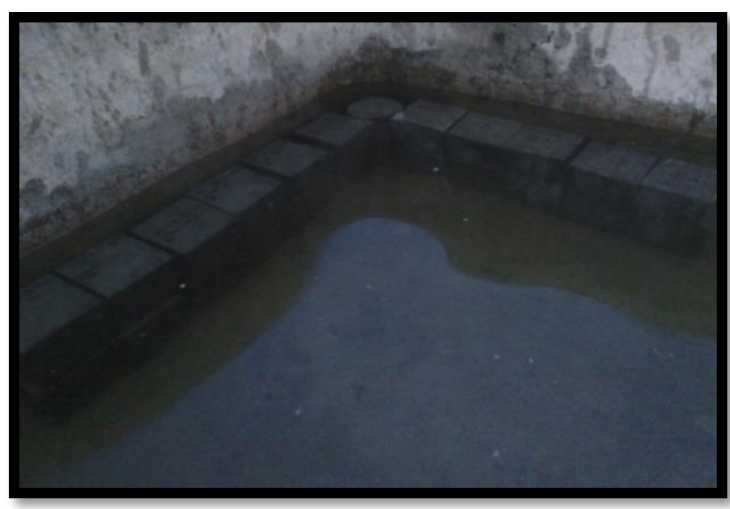

Curing of Specimens

\subsubsection{Compression Strength Test}
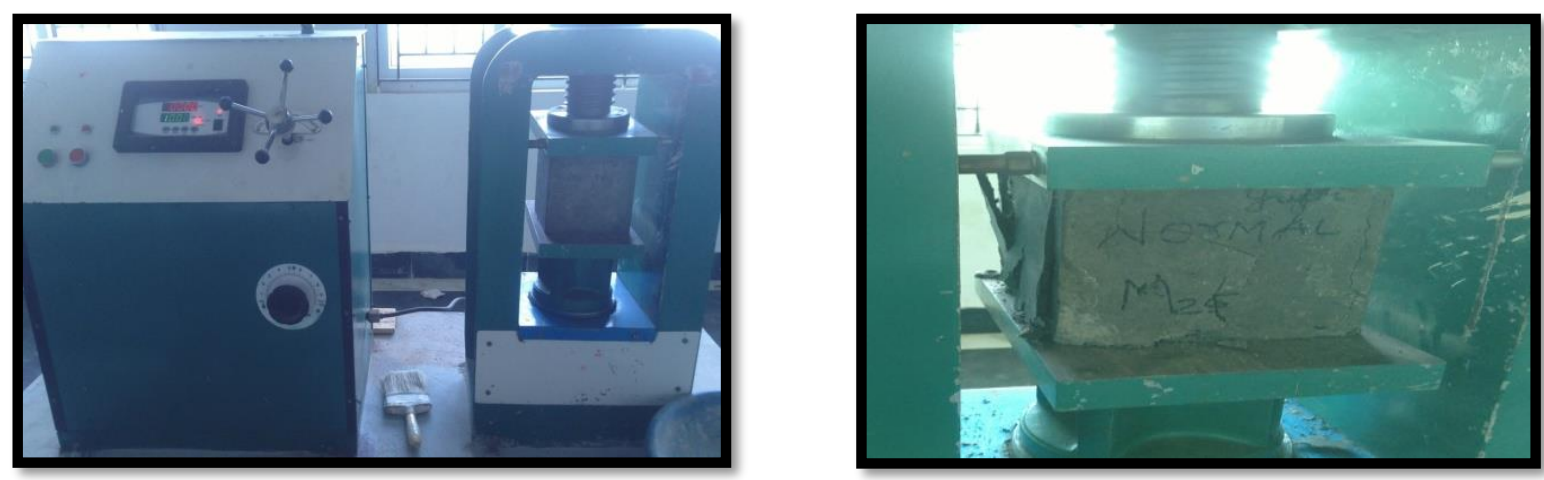

Compressive strength for 28days of concrete cube is done as per IS: $516-1959$ and tabulated in table 1.2

Table 1.2: compression strength of concrete cube 28 days

\begin{tabular}{|c|c|c|c|c|}
\hline S. No & $\begin{array}{l}\text { Cube } \\
\text { Trails }\end{array}$ & $\begin{array}{l}\text { Maximum Load } \\
\text { Applied (Kn) }\end{array}$ & $\begin{array}{c}\text { Compression } \\
\text { Strength }(\mathrm{N} / \mathrm{Mm} 2)\end{array}$ & $\begin{array}{c}\text { Average Compression } \\
\text { Strength (N/Mm2) }\end{array}$ \\
\hline \multirow[t]{2}{*}{1} & \multirow{2}{*}{$\begin{array}{l}\text { Normal } \\
\text { Concrete }\end{array}$} & 1033 & 45.91 & \multirow[t]{2}{*}{46.13} \\
\hline & & 1043 & 46.36 & \\
\hline \multicolumn{5}{|c|}{ REPLACING CEMENT USING SILICA FUME } \\
\hline \multirow[t]{2}{*}{2} & \multirow{2}{*}{$\begin{array}{l}\text { Silica Fume - } \\
5 \%\end{array}$} & 996 & 44.27 & \multirow[t]{2}{*}{44.31} \\
\hline & & 998 & 44.36 & \\
\hline \multirow[t]{2}{*}{3} & \multirow{2}{*}{$\begin{array}{l}\text { Silica Fume - } \\
10 \%\end{array}$} & 1002 & 44.53 & \multirow[t]{2}{*}{44.71} \\
\hline & & 1010 & 44.89 & \\
\hline \multirow[t]{2}{*}{4} & \multirow{2}{*}{$\begin{array}{l}\text { Silica Fume - } \\
15 \%\end{array}$} & 1039 & 46.18 & \multirow[t]{2}{*}{46.24} \\
\hline & & 1042 & 46.31 & \\
\hline \multirow[t]{2}{*}{5} & \multirow{2}{*}{$\begin{array}{l}\text { Silica Fume - } \\
20 \%\end{array}$} & 922 & 40.98 & \multirow[t]{2}{*}{41.2} \\
\hline & & 932 & 41.42 & \\
\hline \multicolumn{5}{|c|}{ REPLACING FINE AGRREAGATE USING GLASS POWDER } \\
\hline \multirow[t]{2}{*}{6} & \multirow{2}{*}{$\begin{array}{l}\text { Glass Powder - } \\
5 \%\end{array}$} & 1103 & 49.02 & \multirow[t]{2}{*}{49.18} \\
\hline & & 1110 & 49.33 & \\
\hline 7 & & 1147 & 50.98 & 51.09 \\
\hline
\end{tabular}




\begin{tabular}{|c|c|c|c|c|}
\hline & $\begin{array}{l}\text { Glass Powder - } \\
10 \%\end{array}$ & 1152 & 51.2 & \\
\hline \multirow[t]{2}{*}{8} & \multirow{2}{*}{$\begin{array}{l}\text { Glass Powder - } \\
15 \%\end{array}$} & 1167 & 51.87 & \multirow[t]{2}{*}{51.67} \\
\hline & & 1158 & 51.47 & \\
\hline \multirow[t]{2}{*}{9} & \multirow{2}{*}{$\begin{array}{l}\text { Glass Powder - } \\
20 \%\end{array}$} & 1474 & 65.51 & \multirow[t]{2}{*}{65.76} \\
\hline & & 1485 & 66 & \\
\hline \multirow[t]{2}{*}{10} & \multirow{2}{*}{$\begin{array}{l}\text { Glass Powder - } \\
30 \%\end{array}$} & 1211 & 53.82 & \multirow[t]{2}{*}{53.93} \\
\hline & & 1216 & 54.04 & \\
\hline \multirow[t]{2}{*}{11} & \multirow{2}{*}{$\begin{array}{l}\text { Glass Powder - } \\
40 \%\end{array}$} & 1125 & 50 & \multirow[t]{2}{*}{50.07} \\
\hline & & 1128 & 50.13 & \\
\hline \multicolumn{5}{|c|}{ REPLACEMENT OF SILICA FUME AND GLASS POWDER IN CONCRET] } \\
\hline \multirow[t]{3}{*}{12} & \multirow{3}{*}{$\begin{array}{l}\text { Silica fume - } \\
15 \% \\
\text { Glass powder - } \\
20 \%\end{array}$} & 1169 & 51.96 & \multirow[t]{3}{*}{52} \\
\hline & & & & \\
\hline & & 1171 & 52.04 & \\
\hline
\end{tabular}

\subsubsection{Result Comparison}

Compression strength test of concrete cube with SF and glass powder replacement is shown in chart 4.1 and 4.2. Compression strength of concrete cubes made with $15 \%$ silica fume and $20 \%$ glass powder replacement is shown in chart 4.3 .

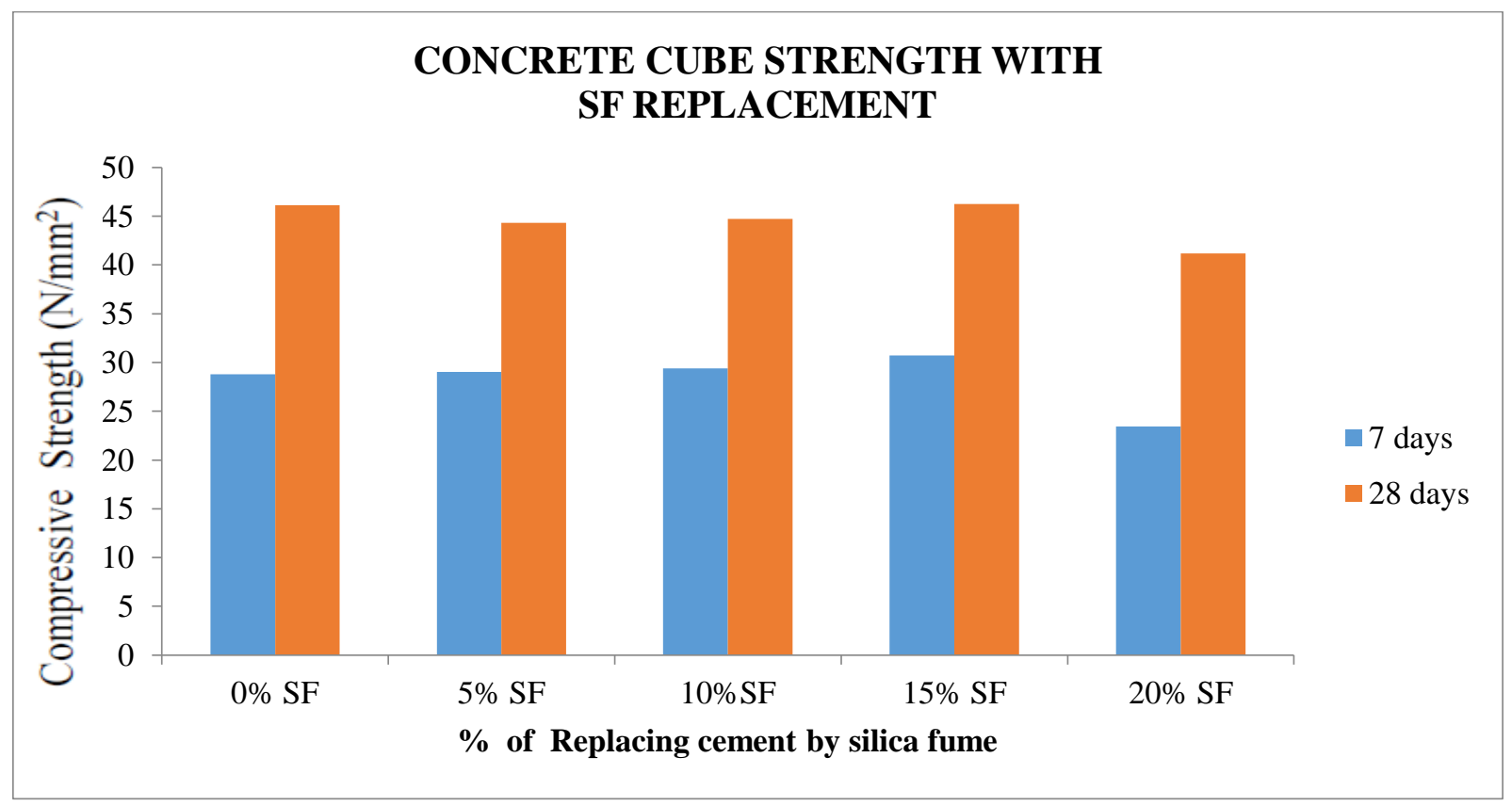

Chart 4.1: Comparison of compressive strength of SF replacement 


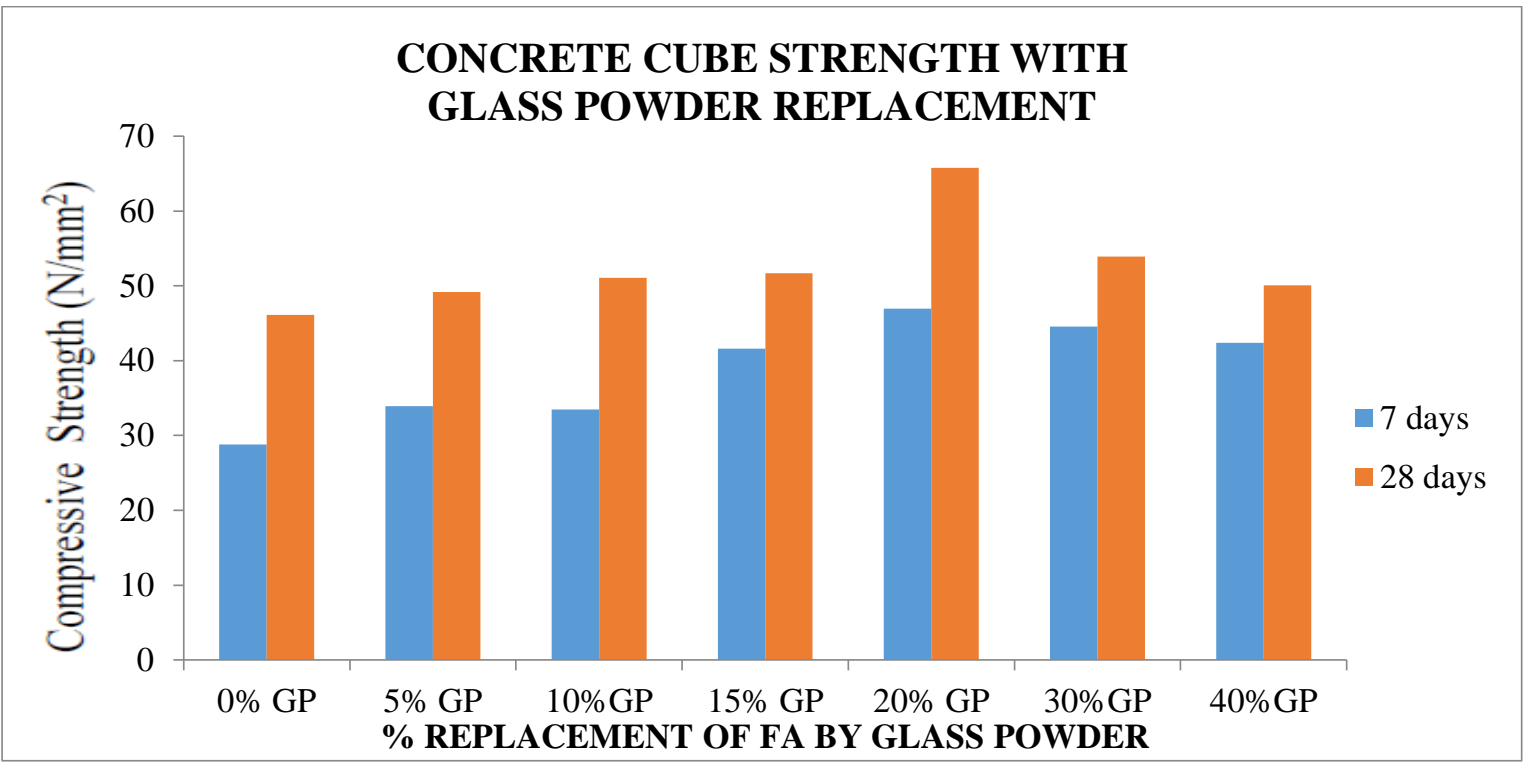

Chart 4.2: Comparison of compressive strength for Glass powder replacement

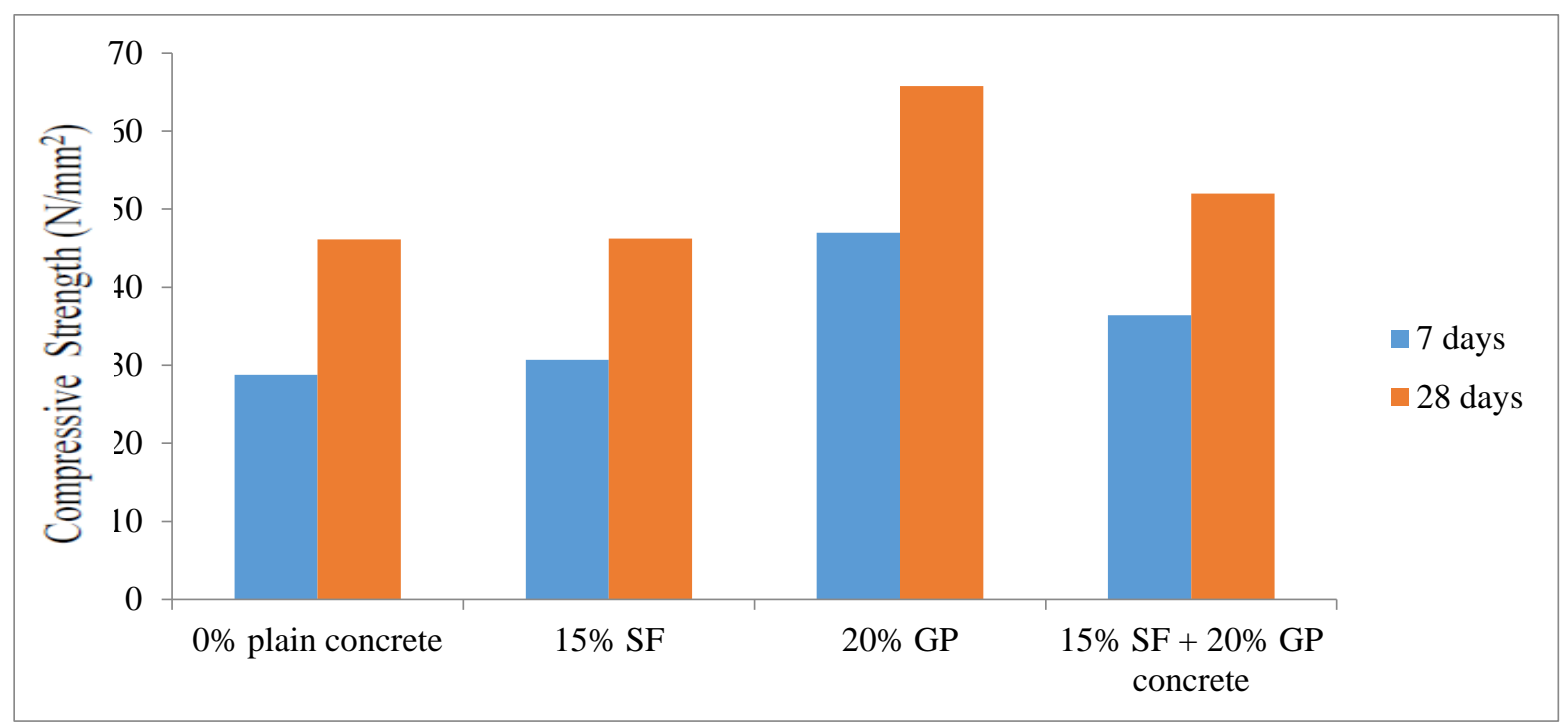

Chart 4.3: Comparison of compressive strength of concrete cube

\section{Conclusion and Recommendations}

In this project it is concluded that study on replacing cement by silica fume and thereby results reveals that silica fume is alternate material for cement. Slump cone test reveals that workability gets affected when silica fume is added at certain percentage. Though silica fume addition decreases workability it gives high compressive strength and also economical. Increase in compressive strength is due to particle size distribution of glass powder.

The project aim is to replace higher percentage of SF and GP in a single concrete together and find its strength. We have concluded from the results that cost and quantity of materials is reduced by using SF and GP together in single concrete cube. 
Following conclusions are made based on results obtained:

- The strength of replacement of highest percentage of SF and GP together in concrete is more than conventional concrete.

- The highest percentage of SF is $15 \%$ and GP is $20 \%$ that can be replaced in concrete gives maximum strength with this replacement percentage.

- Both SF and GP concrete give higher strength then conventional concrete

- SF and GP can be replaced together in concrete to reduce cost and usage of cement and natural resources.

- SF can be used as replacement material for reducing usage of cement and to make high strength concrete and highly permeable one.

- Being light weight glass powder is available as free or less of cost.

- Using glass powder in concrete in one of best way of disposing a waste material

- Over usage of river sand can be controlled by using glass powder

- Even though price of replaced material in concrete are little higher than conventional concrete, natural sources and cement can be saved.

\section{References}

[1] Verma Ajay Verma Ajay, Chandak Rajeev and Yadav R.K, "Effect of Micro Silica On The Strength Of Concrete with Ordinary Portland Cement", Research Journal of Engineering Sciences, Vol. 1, No.3, sept 2012, 1-4.

[2] Dilip Kumar Singha Roy and Amitava Sil, "Effect of Partial Replacement of Cement by Silica Fume on Hardened Concrete", International Journal of Emerging Technology and Advanced Engineering, Vol. 2, Issue 8, Aug 2012.

[3] Vikas Srivastava 1, V.C. Agarwal and Rakesh Kumar, "Effect of Silica fume on mechanical properties of Concrete", J. Acad. Indus. Res, Vol. 1, No.4, Sept 2012.

[4] Vishal S. Ghutke and Pranita S.Bhandari "Influence of silica fume on concrete", IOSR Journal of Mechanical and Civil Engineering, 2014, 44-47.

[5] Debabrata Pradhan and Dutta (2013), Debabrata Pradhan and D. Dutta "Influence of Silica Fume on Normal Concrete", Int. Journal of Engineering Research and Application, Vol. 3, Issue 5, SepOct 2013,79-82.

[6] Faseyemi Victor Ajileye "Investigations on Microsilica (Silica Fume) As Partial Cement Replacement in Concrete", Global Journal of researches in Engineering, 2013

[7] M. Iqbal Malik, Muzafar Bashir, Sajad Ahmad, Tabish Tariq and Umar Chowdhary, "Study of Concrete Involving Use of Waste Glass as Partial Replacement of Fine Aggregates", IOSR Journal of Engineering, Vol. 3, Issue 7, July. 2013, 08-13.

[8] Jostin.P.jose , S.suganya and Banu Priya, "Use Of Glass Powder As Fine Aggregate In High Strength Concrete", International Journal of Science and Engineering Research (IJ0SER), Vol. 2, Issue 7, july-2014.

[9] Haider K. Ammash, S. Muhammed, Ali and H. Nahhab Babylon, "Using of Waste Glass as Fine Aggregate in Concrete", Al-Qadisiya Journal for Engineering Sciences, Vol. 2, 2009.

\footnotetext{
*Corresponding author.

E-mail address: anburajesh24890@ gmail.com
} 